\title{
AN OPTIMALIZATION OF NATURAL LIGHTING BY APPLYING AUTOMATIC LIGHTING USING MOTION SENSOR AND LUX SENSOR FOR HISTORICAL OLD BUILDINGS ${ }^{1}$
}

\author{
Saeful Bahri ${ }^{2}$ dan Ari Widyati Purwantiasning ${ }^{3}$ \\ ${ }^{2}$ Jurusan Teknik Elektro Universitas Muhammadiyah Jakarta \\ 3 Jurusan Arsitektur Universitas Muhammadiyah Jakarta \\ saefulbahri2003@yahoo.com, arwityas@yahoo.com
}

\begin{abstract}
One of the problems that occurs within city centres, particularly within capital cities, is the existence of many historical old buildings. Historical old buildings within city centres, that have abandoned for years because of their condition, suffer from a lack of utilities, infrastructure and facilities [2][3]. These conditions occur because of low levels of maintenance arising as a consequence of a lack of finance of the owner of a building, be they government or private sector. To solve the problem of abandoned historical old buildings, the concept of adaptive reuse can be adopted and applied. This concept of adaptive reuse may continously cover the cost of building maintenance. The adaptive reuse concept usually covers the interior of a building and its utilities, though the need for utilities depends on the function of a building [4]. By adopting a concept of adaptive reuse, new building functions will be designed as the needs and demand of the market dictate, and which is appropriate for feasibility study. One utility element that has to be designed for historical old buildings is the provision of lighting within a building. To minimize the cost of building maintenance, one of the solutions is to optimize natural lighting and to minimize the use of artificial lighting such as lamps. This paper will discuss the extent to which artificial lighting can be minimized by using automatic lighting; the automatic lighting types discussed in this paper are lighting controlled by motion sensor and lux sensor.
\end{abstract}

Keywords: Natural lighting, automatic lighting, motion sensor, lux sensor, historical old buildings

ABSTRAK Salah satu permasalahan yang muncul dalam sebuah kota metropolitan, khususnya sebuah ibukota adalah keberadaan dari banyaknya bangunan-bangunan tua bersejarah. Bangunanbangunan tua bersejarah dalam sebuah kota besar terutama yang diabaikan selama bertahun-tahun biasanya disebabkan karena kondisinya yang menua, minimnya utilitas bangunan, infrastruktur bangunan dan juga fasilitas-fasilitas yang mendukungnya [2][3]. Kondisi ini muncul karena rendahnya tingkat pemeliharaan yang biasanya muncul sebagai akibat dan konsekuensi karena minimnya dana anggaran dari pihak pemilik bangunan baik pemerintah daerah, pusat maupun sector swasta. Untuk mengatasi masalah ini, konsep adaptive reuse dapat diadopsi dan diaplikasikan pada kawasan yang memiliki bangunan-bangunan tua bersejarah ini. Konsep adaptive reuse dapat secara berkelanjutan memenuhi dan mengatasi permasalahan pemeliharaan bangunan dalam hal finansial. Konsep ini biasanya meliputi ruang dalam bangunan dan utilitas yang ada di dalam bangunan tersebut tergantung dari kebutuhan dan fungsi dari bangunan yang akan diaplikasikan konsep tersebut [4]. Dengan mengadopsi konsep adaptive reuse, fungsi bangunan baru dapat direncanakan sesuai kebutuhan dan permintaan pasar sehingga sesuai dengan studi kelayakan yang dilakukan. Salah satu elemen utilitas bangunan yang dapat dirancang untuk bangunan-bangunan tua bersejarah adalah kebutuhan pencahayaan di dalam sebuah bangunan. Untuk meminimalisir biaya pemeliharaan bangunan, salah satu solusinya adalah dengan mengoptimalkan pencahayaan alami dan meminimalisir penggunaan cahaya buatan seperti lampu. Tulisan ini akan mendiskusikan seberapa jauh pencahayaan buatan dapat diminimalisir dengan menggunakan pencahayaan otomatis, dimana dalam tulisan ini akan dibahas mengenai control pencahayaan dengan menggunakan motion sensor atau sensor gerak dan lux sensor atau sensor cahaya.

Kata Kunci: pencahayaan alami, pencahayaan otomatis, motion sensor, lux sensor, bangunan tua bersejarah

\footnotetext{
${ }^{1}$ Penelitian ini merupakan hasil penelitian kolaborasi antara Dosen Jurusan Teknik Elektro dan Jurusan Arsitektur Universitas Muhammadiyah Jakarta dan telah dipaparkan dalam Seminar Internasional The $6^{\text {th }}$ International Seminar on Urban Planning Policies and Strategies For Revitalization, Universidad Nacional del Nordeste, Resistencia, Argentina, 04-05 June 2015
} 


\section{INTRODUCTION}

The issue of global warming has opened up awareness to all parties of the importance of nature preservation. Global warming is a process that occurs at temperatures in the troposphere; this warming occurring as a result of human activities on the earth's surface, particularly from industrial activities as well as glasshouse effect of the buildings. To reduce or slow the increase of global warming, it is important to underline how to do preventive actions. One such action is to apply an environmentally friendly, green building concept [5]. General application of green design concepts will be effective when the building industry supports it, by developing materials and construction technologies that are environmentally friendly. Historical old buildings within Jakarta Old Town Area, for example, could be designed using a green design concept by applying automatic lighting to minimize the use of artificial lighting.

This research is aimed at exploring, understanding and describing how the concept of green architecture has been applied in design and planning, particularly in the adaptive reuse concept of historical old buildings. The research will discuss the extent to which design can optimize the use of natural climate, especially within the tropical country of Indonesia [5]. The natural climates which will be discussed relate to natural lighting within historical old buildings. Furthermore, the research will discuss the extent to which artificial lighting could be minimized by using automatic lighting. Automatic lighting discussed in this paper are lighting controlled by motion sensor and lux sensor.

\section{DEFINITION OF NATURAL AND ARTIFICIAL LIGHTING}

Lighting can be defined as a necessary factor in order to have a comfortable and safe environment, either indoors or outdoors, that is related to human productivity. Good lighting supports people to see significant objects clearly and quickly. Generally, there are two kinds of lighting system; natural lighting and artificial lighting [1].

Natural lighting is lighting related to sunlight. Natural lighting has many benefits for human life. Firstly, natural lighting can minimize the cost of electricity energy use and demolish bacteria and germs. To get optimal natural lighting, we need to provide big windows or glass walls at least $1 / 6$ th of the floor area. Natural lighting resources sometime cannot be used optimally because the lighting intensity is unpredictable due to the climate conditions.

There are a number of factors that could be of concern in using natural lighting, as follows:

1. Variety of intensity of sun lighting;

2. Distribution of the light;

3. The effect of location, light reflection, and space between buildings;

4. Geographical location and the function of the building

The Department of Settlement and District Infrastructure, representing the central government of Indonesia, profesional associations, consultants, contractors, building maintenance departments and universities, has delivered a standard of "methods of natural lighting system design for building". It has been stated that, natural day lighting could be said to be good enough if:

1. Between 08.00 AM to 04.00 PM local time, there is enough daylight entering the room

2. Distribution of daylight in the room is prevalent

On the other hand, artificial lighting could be defined as lighting which has been produced by lighting resources other than natural lighting. Artificial lighting is always needed as lighting that will be used at night or even when natural lighting cannot support enough light within a room. The main function of artificial lighting, either when applied individually or in combination with natural lighting, can be explained as follows:

1. Creation of an environment for people where it is possible to see everything in detail and where vision is clear enough for completion of their activity;

2. Creation of an environment that is walkable and where movement can be done easily and safely;

3. Creation of a workplace that does not have high humidity;

4. Provision of lighting with permanent intensity and prevalent distribution;

5. Enhancement of a comfortable visual environment and improved performance 


\section{DEFINITION OF AUTOMATIC LIGHTING}

Nowadays, the term smart building can be defined as modern building that is automatically adapted to environmental conditions in order to provide comfort, simplicity and safety for the user [6]. A further well known concept is the Building Automation System, which refers to a system that not only controls one aspect of automation within a building but also to many other aspects related to the building function and the needs of the users. This research will discuss the automation system in lighting known as automatic lighting. Basically, within this concept, the user can control the need for lighting using electronic devices, either inside or outside the building, through the use of one small device as a form of central control usually installed at the main entrance. Users can control all the electricity used within a building before they leave it by checking that central control point.
There are two main components of automatic lighting systems, the motion sensor and the lux sensor. Both components have their own characteristics. Motion sensors detect movement of the user; for example, when entering a bedroom, all the lighting within the room will be turned on automatically, and turned off again soon after the user leaves the room. The lighting within the bedroom will always remain turned on while there is movement within the room whilst, on the otherhand, it will turn off when there is no movement within the room. The second component, i.e. the lux sensor, is usually used to control artificial lighting when the natural lighting is not sufficient to light a room; automatically, a light will turn on soon after a room is not getting enough light from natural lighting. This system has usually been used for public lighting along the street or main road, with the lamp lighting automatically turning on after it gets dark.

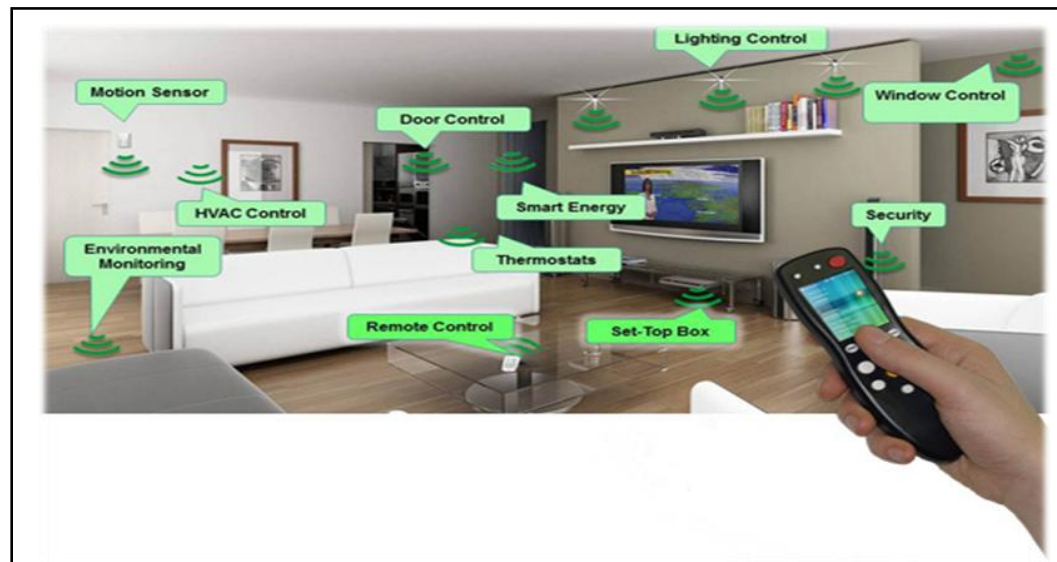

Figure 1: Examples of automatic sensor using remote control (Source: Ondang, 2003)[1]

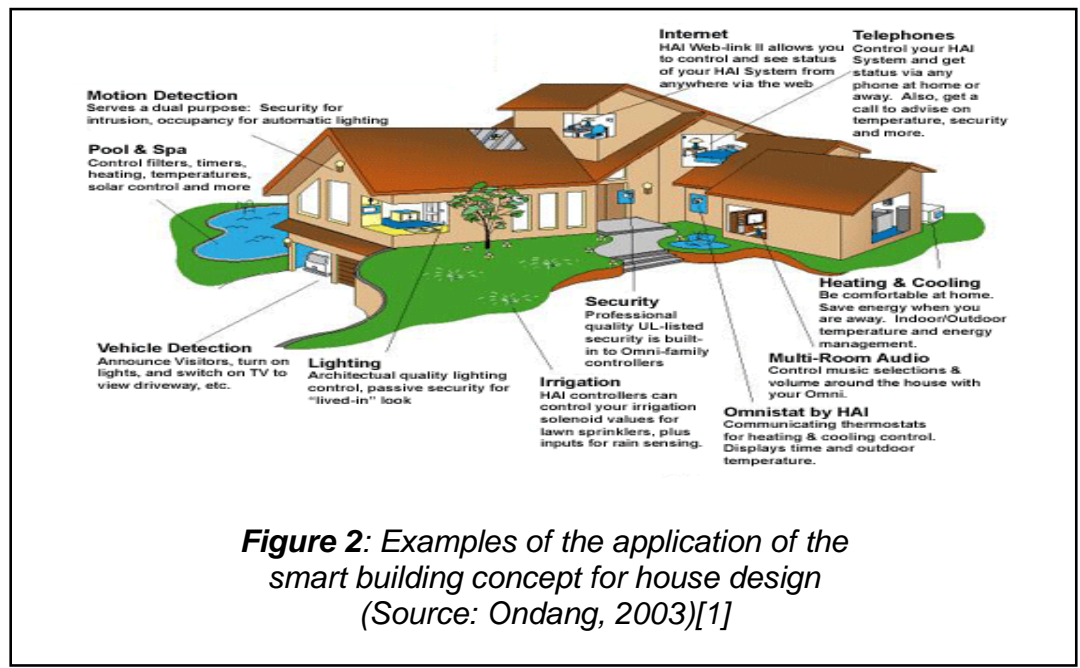


Both of the systems are usually implemented in parallel using bellow sensor devices, as follows:

1. LDR (Light Dependent Resistors), as a lighting detector;

2. PIR Sensor (Passive Infra Red Sensor), as a motion detector based on infra red radiation from human body;

3. Microcontroller, as a form of command sensor distribution to lighting devices.

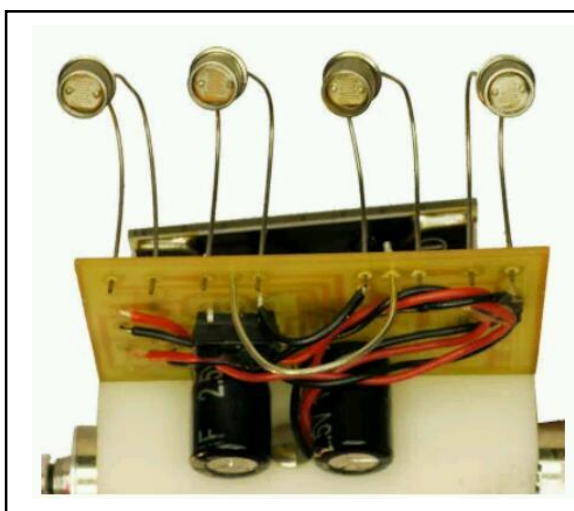

Figure 3: LDR or Light Dependent Resistors

(Source: Ondang, 2003)[1]

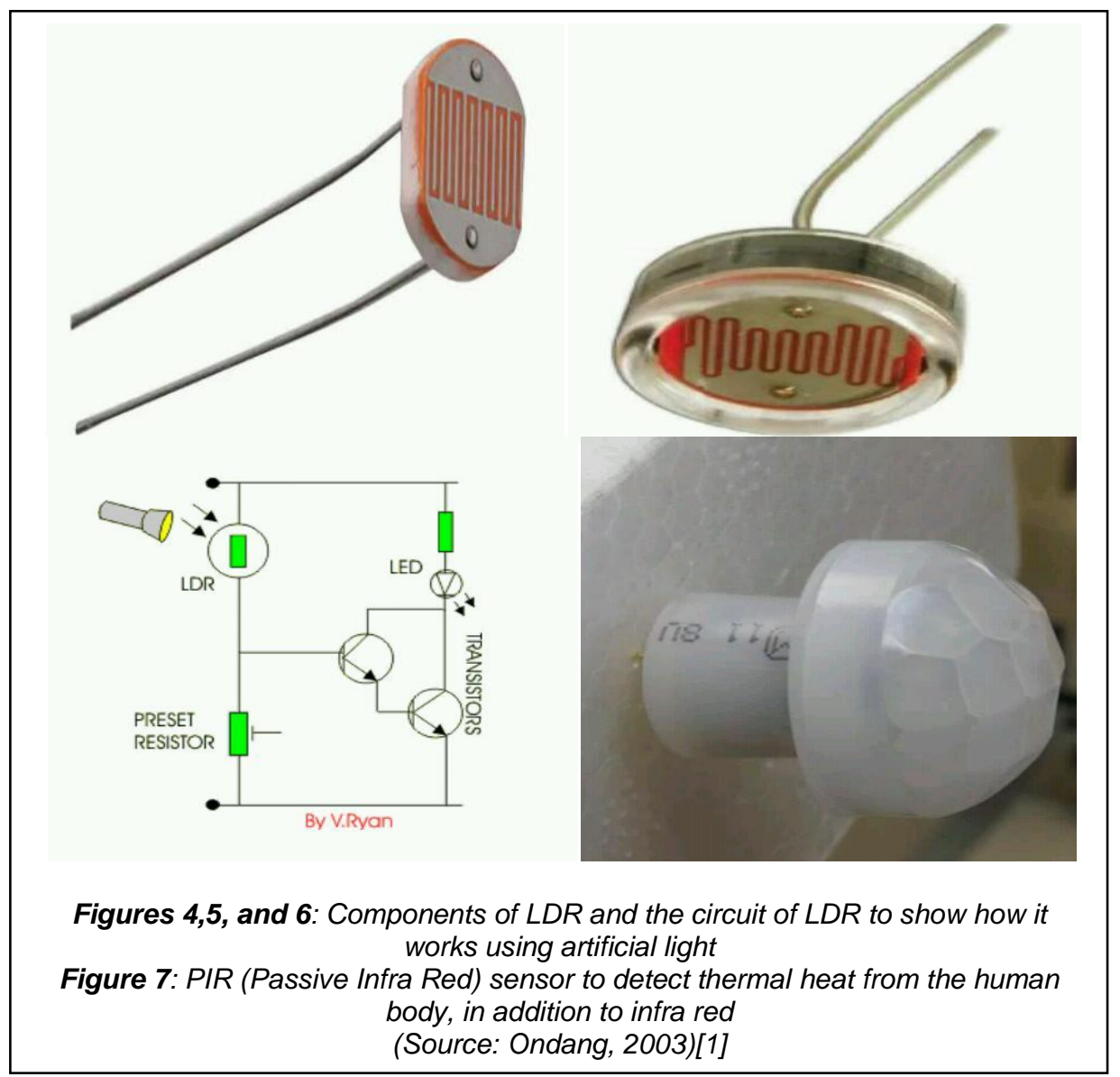




\section{CLASSIFICATION OF HISTORICAL OLD BUILDINGS}

In reference to historical aspects, as well as architectural aspects, designated buildings for conservation within Jakarta Old Town Area [4], in particular, and within Indonesian Heritage sites, in general, can be classified into 4 different classes as follows [4]:

Grade A: Historical old buildings with high architectural value. These kind of buildings can not be changed, added to, destroyed or rebuilt.

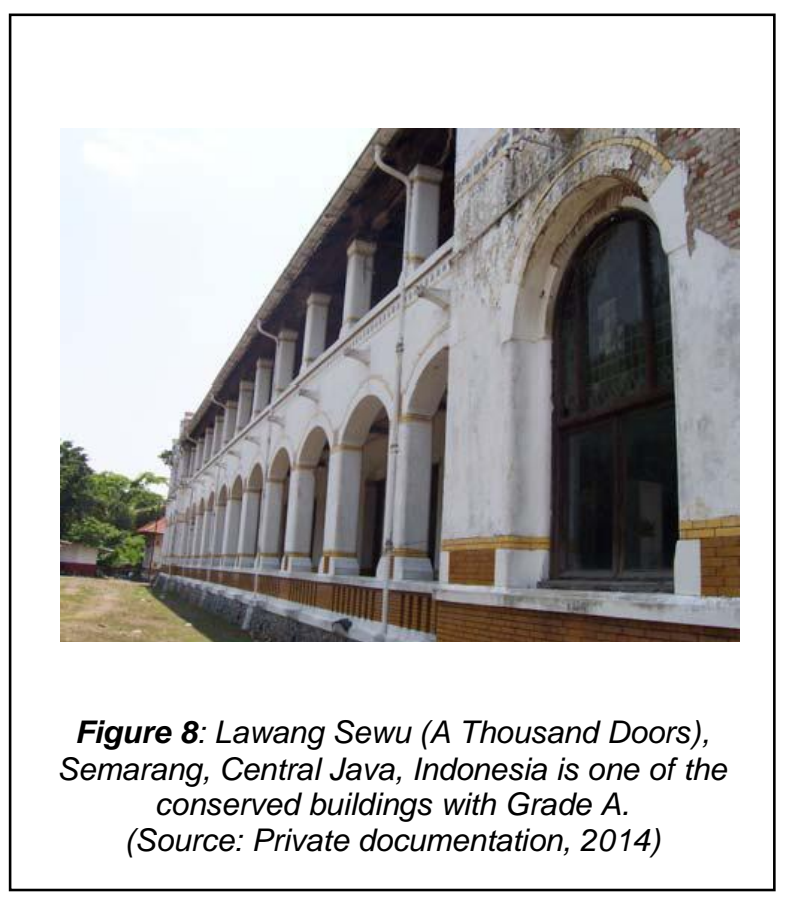

Grade B: Historical old buildings with specific character of the form with a good structure, creating a better environment and a harmonious living space.

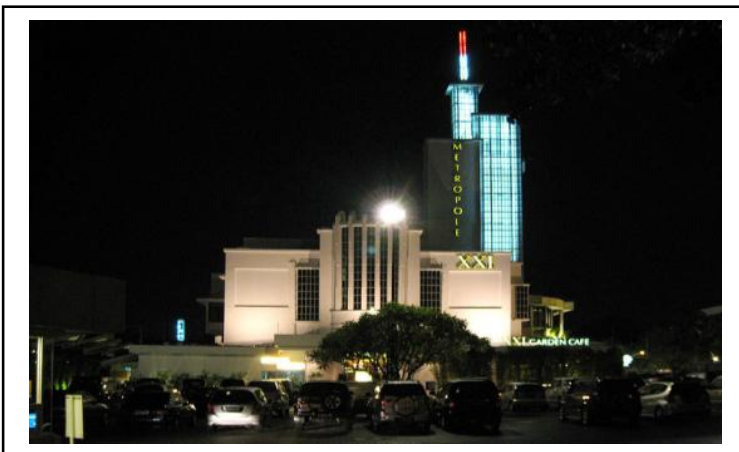

Figure 9: Jakarta Old Theatre well known as Megaria, Indonesia

(Source: http://wismusadono.blogspot.com/, 2011)
Buildings with this classification cannot have their main structure, main roof or facade changed. Changes can be made to the interior of the buildings, as well as some destroyed elements, however the form of the building should remain the same.

Grade C: Historical old buildings with so many changes because the condition is so bad; thus, buildings in this class can be changed and rebuilt again, however the changes should still follow the facade pattern of the surrounded buildings. Basically, the new building should be in keeping with the context of the old one.

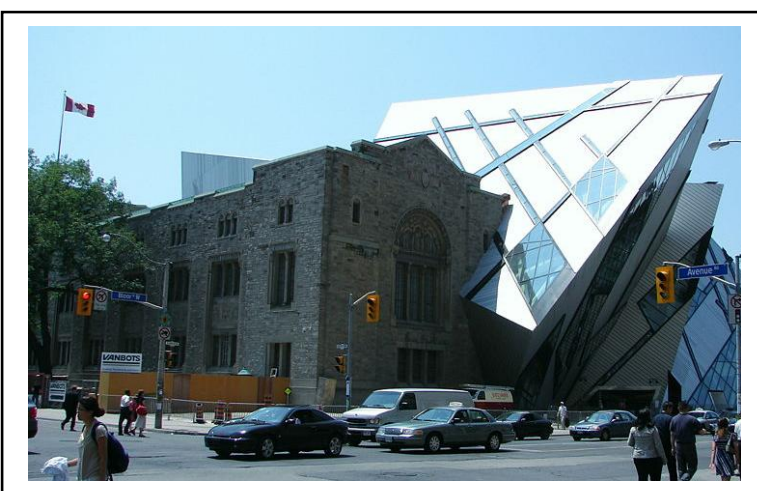

Figure 10: Historical building of Royal Ontario Museum, Canada

(Source: http://wismusadono.blogspot.com/, 2011)

Grade D: Buildings with this classification are all historical old buildings which can be totally changed because the building has been destroyed and cannot be protected anymore. These buildings can be rebuilt with urban planning showing concern for the environmental scale so that works will not disturb the surrounding area.

\section{AN APPLICATION OF AUTOMATIC LIGHTING FOR HISTORICAL OLD BUILDINGS}

It has been proposed to adopt a concept of adaptive reuse for historical old buildings within Jakarta Old Town Area through adoption of a concept of green building which will designed by applying automatic lighting within buildings. In everyday operating systems, buildings are one of the objects which usually need energy for users, particularly lighting energy. To maintain the 
effectiveness and efficiency in using lighting energy, one of the concepts which can be applied is the use of automatic lighting within a building. There are a number of aspects of concern in planning automatic lighting, such as the active design aspect, passive design aspect, the condition of room temperature, and its management, service and maintenance. Active and passive design can be conducted at the beginning of planning, however if a building has already been built, a process of retro-fit can be applied at particular parts. The condition of room temperature, management, service and maintenance, on the other hand, can be conducted at the operating phase of the building.

Passive Design can be defined as a design that could be implemented as part of the building that is not actively functioned or passively functioned during the operating phase. Examples of passive design are as follows:

a. Building forms that minimalize the entry of sunlight. The entry of direct sunlight can be controlled and the load due to use of Air Conditioner minimized;

b. The colour and material for the secondary skin or building facade can be chosen to minimize direct sunlight;

c. The choice of planting and the proportion of garden within the site area;

d. The use of fountain and water elements within a site to help to control the temperature surrounding buildings;

e. A significant indicator of the concept of passive design is OTTV (Overall Transfer Thermal Value) which can be affected by the choice of materials and the colour of the secondary skin of the facade.

Active Design is usually applied to certain parts of a building which are active when the buildings is operational, for example, as follows:

a. Air conditioning design can be estimated accurately between the cooling capacity, the room capacity and its users;

b. Lighting systems can be used optimally according to the level of good lighting and safe energy usage;

c. Other utility tools can be used to estimate the energy load and solar cells can be used to replace electricity energy.
Active design has a significant impact on energy consumption, because all active tools use electricity or water energy. The aspect of the condition of room temperature has a significant impact on the usage of the power of the cooling machine because the lower the room temperature the higher the electricity energy use. To control room temperature, there are certain actions that can be taken as follows:

a. For common areas, the temperature can be controlled centrally through a control room or BAS (Building Automation System);

b. For private areas, separate zones can be created (if using a central air conditioner) or separate apartment units with separate metre systems.

Usually, good energy strategies applied to buildings should originate from good building management. Energy management can be applied by establishing an energy team that is responsible for building energy maintenance. A building maintenance program, applied regularly with an effective maintenance process, will make a positive contribution to the level of energy usage.

Lighting control systems have a function of controlling the light based on the input from a sensor, well known examples being the lux sensor and the motion sensor. By using this system, electricity energy consumption can be reduced to a minimum whilst satisfying the needs of the users. This system will automatically reduce the building maintenance of old buildings that have been redesigned by using the adaptive reuse concept. The automation system of this artificial lighting can be connected to the lighting panel and, therefore, the building lighting zones can be controlled from the main control panel. 


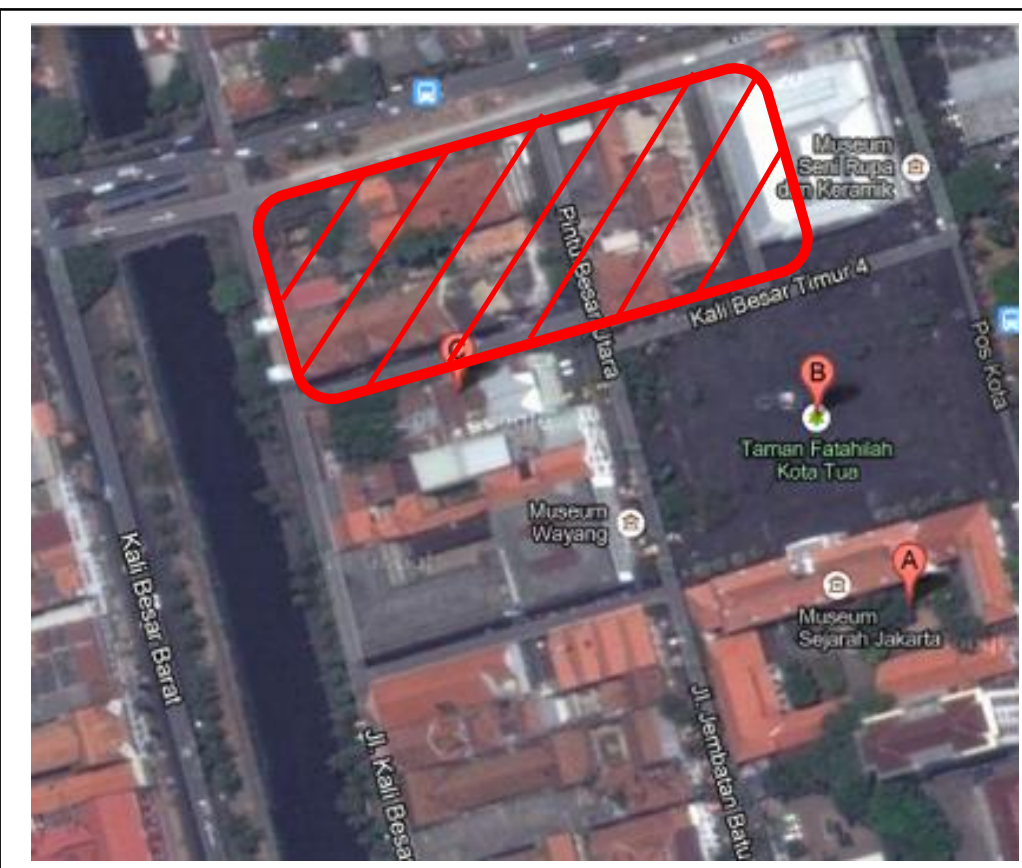

Figure 11: Historical building of PT PPI ex PT Tjipta Niaga within the Jakarta Old Town Area

(Source: Google Maps, 2014)

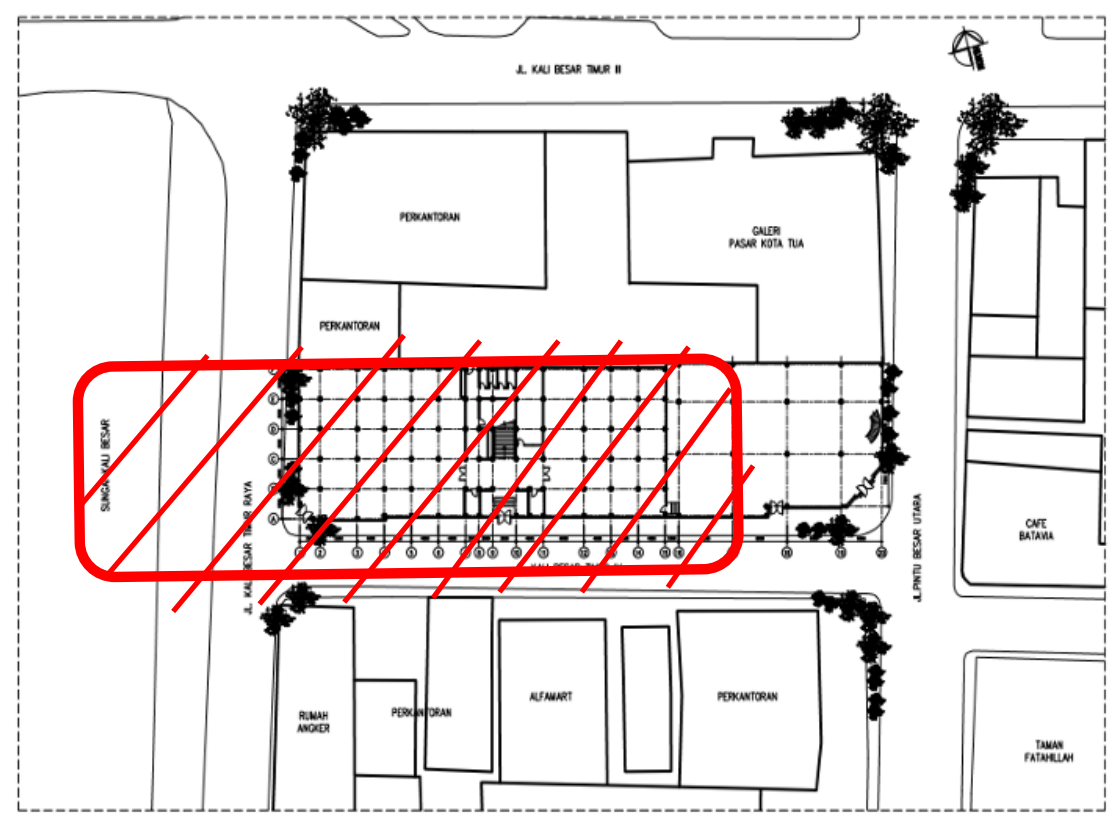

SIIE PLAN

Figure 12. Site Plan of PT PPI ex PT Tjipta Niaga within the Jakarta Old Town Area (Source : Retdia, 2014; redraw for Analysis, 2015)[4] 
Figure 11 shows the location of PT PPI Ex PT Tjipta Niaga Building which is in a very bad condition. The local government of Jakarta has been encouraged to redesign the building to have a new function as a hotel and gallery for the Jakarta Old Town Area. As an application of automation smart building, the researcher has tried to apply automatic lighting within this proposed design to minimize the artifical lighting used. As an application of automation lighting within this old building, the researcher aims to use the MESL System (Multi Energy Save Load) combined with the sun shading within the form of the building. These efforts could, hopefully, minimize the use of artificial lighting and optimize the amount of natural lighting. As a control method, it will use:

1. An ON-OFF selector, which can be operated completely with LED monitoring of the load position;

2. The INPUT for many sensors as well as interfacing, as all the load control can be programmed as individualgroup or pattern to the load or all off/all on, despite the individual control. All of it would fulfill good intelligent control and be user friendly.

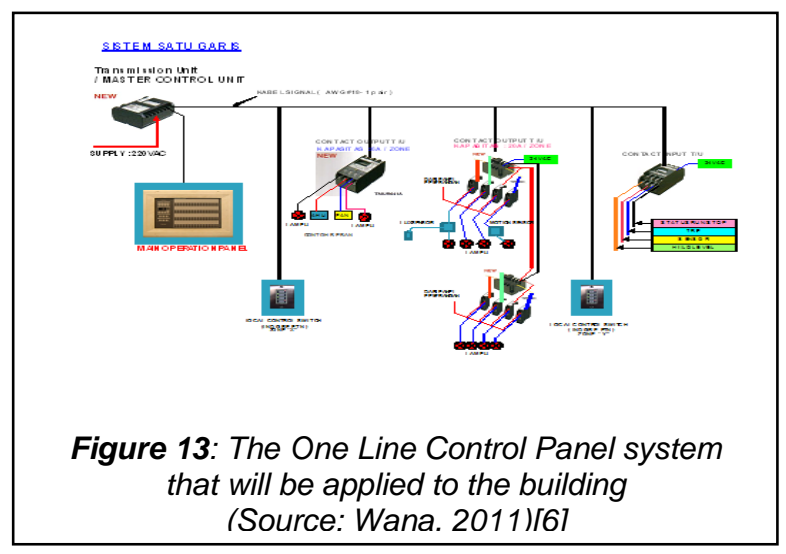

How the Motion Sensor works:

1. Human temperature will be detected by motion detector/ infra red sensor;

2. The sensor will send an ON signal to the control switcher until the light is $\mathrm{ON}$;

3. When there is no one coming, the sensor will detect under the setting temperature, and thus the timer and dimmer will start to work;

4. The dimmer will work until the light goes down until finally the light will be OFF depending on the setting of the time delay;
This system will reduce the energy consumption from $30 \%-60 \%$ compared to a conventional switcher.

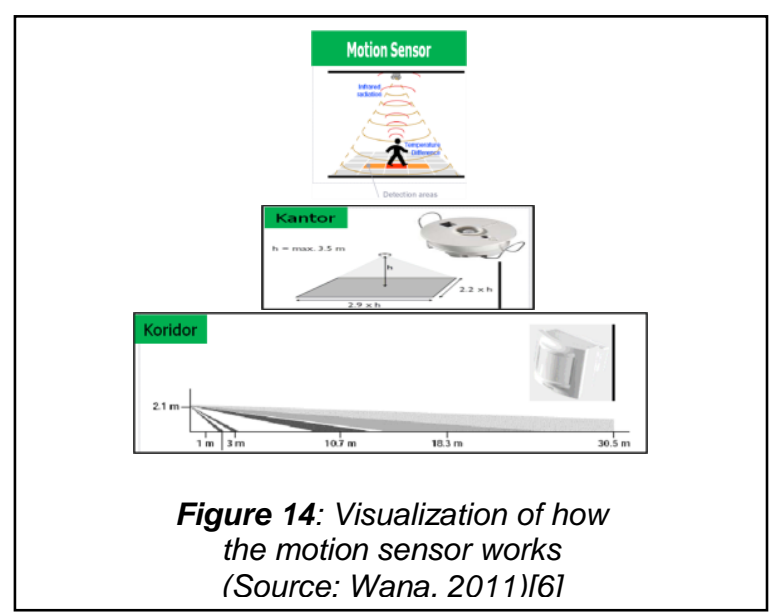

How the Lux Sensor works:

1. The lux sensor will detect the intensity of the light within the room (lux) from the floor reflection;

2. The dimmer will work according to the lux level. There are two conditions, either light up or light down depending on the intensity of the light within the room;

3. The setting of the lux sensor will be affected by the height of the room and the design of natural lighting (windows, doors, etc)

This system will reduce the energy consumption from $30 \%-60 \%$ because the demand on the lux depends on the needs of the users.

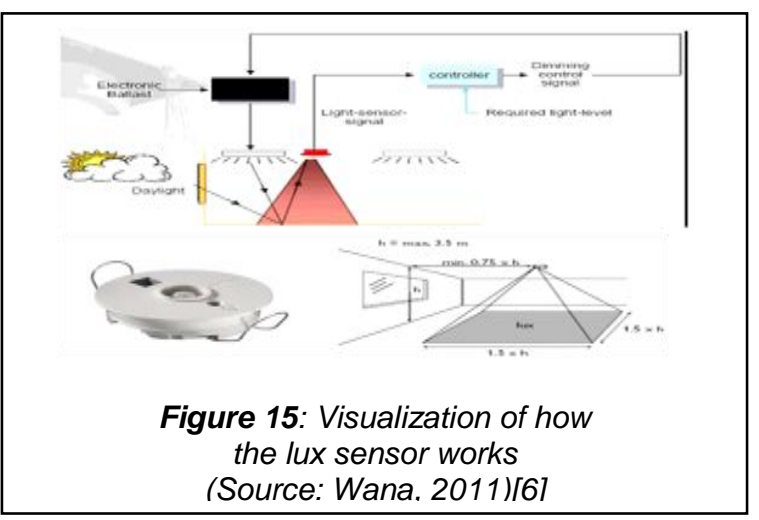



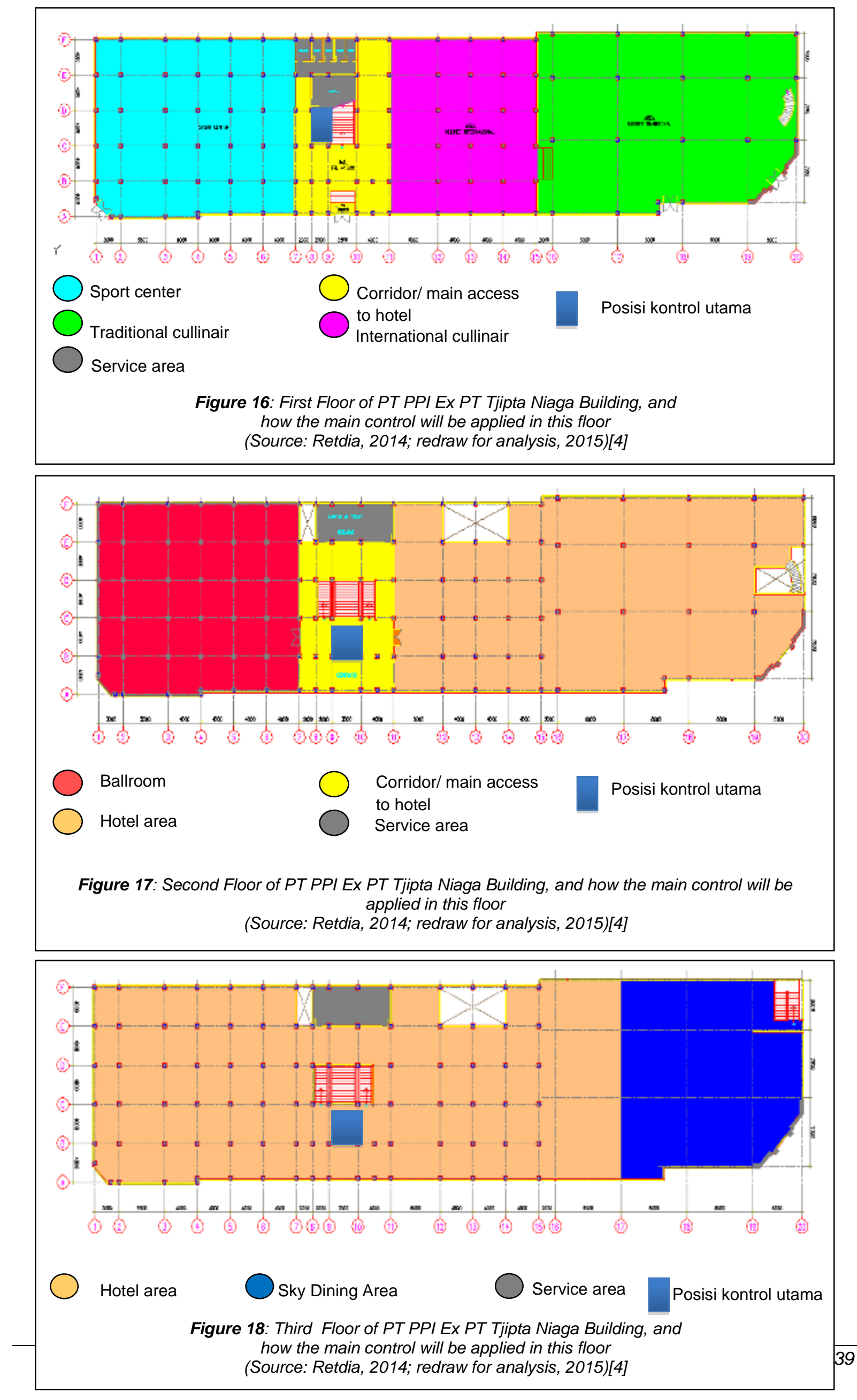


\section{CONCLUSION}

As one of the efforts to maintain the historical old buildings within the Jakarta Old Town Area, the local government has been encouraged to deliver a concept of adaptive reuse with new functions for old buildings. To support this initiative, the researcher has proposed a green building concept which could minimize building costs, particularly in terms of artificial lighting usage. It has been proven that the application of automation lighting, particularly by using the system of motion sensor and lux sensor, could reduce energy use by about $30 \%-60 \%$. The optimalization of natural lighting usage could also be applied according to the design of the adaptive reuse concept.

\section{REFERENCES}

[1] Ondang, Ixnando. (2003). Sistem Otomatisasi Pencahayaan. Universitas Sam Ratulangi.

[2] Purwantiasning, Ari Widyati. (2009). Konversi Bangunan Tua Sebagai Salah Satu Aplikasi Konsep Konservasi. Jurnal Arsitektur Universitas Muhammadiyah Jakarta Nalars. Volume 8 Nomor 2. Juli 2009.
Universitas Muhammadiyah Jakarta. Jakarta. Indonesia.

[3] Purwantiasning, Ari Widyati \& Mauliani, Lily \& Aqli, Wafirul. (2013). Building Conversion As An Application Of Old Building Conservation, Comparative Studies: China Town Singapore, Petak Sembilan Jakarta. Proceeding International Seminar Genius Loci. Universitas Negeri Makassar. 14-16 Februray 2013. Universitas Negeri Makassar. Indonesia.

[4] Purwantiasning, Ari Widyati \& Sofiana, Retdia \& Anisa. (2014). Strategi Penerapan Konsep Adaptive Reuse Pada Bangunan Tua, Studi Kasus: Gedung Pt Ppi Ex. Kantor Pt Tjipta Niaga. National Seminar Semnastek 2014. 12 November 2014. Fakultas Teknik Universitas Muhammadiyah Jakarta. Jakarta.

[5] Setyowati, Endang. (2009). Green Architecture Pada Disain Rumah Tinggal: Pemanfaatan Iklim Alam. Universitas Muhammadiyah Jakarta.

[6] Wana, Gita. (2011). Penghematan Konsumsi Listrik Pada Penerangan Berdasarkan Konsep Green Building. Universitas Muhammadiyah Jakarta. 